\title{
Parental perception versus the presumption of the occurrence of dentoalveolar trauma in their children
}

\author{
Percepção dos pais frente à pressuposição da ocorrência \\ de lesões traumáticas dentoalveolares em seus filhos
}

\author{
Paula Gabriela de Oliveira FLORA ${ }^{1}$ iD https://orcid.org/0000-0002-5402-8223 \\ Lilian Citty SARMENTO ${ }^{1}$ iD https://orcid.org/0000-0002-0409-1638 \\ Ana Paula Martins GOMES1 1 iD https://orcid.org/0000-0002-1064-0322 \\ Ana Maria Martins GOMES ${ }^{1}$ iD https://orcid.org/0000-0001-7869-248X \\ Marly Almeida Saleme do VALLE' ${ }^{1}$ iD https://orcid.org/0000-0002-8496-5197 in memoriam \\ Elâine Cristina Vargas DADALTO ${ }^{1}$ iD https://orcid.org/0000-0002-1698-3326
}

\section{ABSTRACT}

Objective: This cross-sectional, observational study sought to ascertain the perception of parents vis-à-vis the presumption of a dentoalveolar trauma, with regard to the main sequelae, social relationships, expected reactions of the children, and the feelings of the child. Methods: A total of 74 parents were selected at random, who were presented with six color photographs taken from a book, having the clinical appearance of traumatic injury. The responses were recorded with the aid of a voice recorder and were transcribed and stratified using semantic approximation. The data were tabulated using the SPSS software program and evaluated using descriptive statistics. Results: The main sequelae ascribed to dentoalveolar trauma by the parents were as follows: loss of the tooth $(43 \%)$ and damage to the permanent tooth (18\%). The majority of parents believed there would be no change in terms of the children's relationship with their parents (68.9\%), while for $54.1 \%$, there might be some alienation by children in the neighborhood, and for $90.5 \%$, schoolchildren might tease or make fun of them. Of the expected reactions, $86.5 \%$ of parents believed their child would feel differently in relation to their friends, because of their appearance. With regard to feelings, for $85.1 \%$, the trauma could lead to the children experiencing shame or embarrassment, $79.7 \%$ replied shyness or introversion, and $60.8 \%$ sadness. Conclusion: It was concluded that the loss of a tooth and the risk of involvement of the permanent successor tooth germ were the main sequelae ascribed by the parents. Dentoalveolar trauma may have a detrimental effect on the social relationships of the children with others in the neighborhood, and mainly at school, and they may feel differently towards their friends on account of their appearance. Moreover, the children may experience shame or embarrassment, shyness or introversion, and sadness.

Indexing terms: Child. Psychosocial impact. Tooth injuries.

\section{RESUMO}

Objetivo: Esta pesquisa observacional transversal objetivou verificar a percepção de pais, frente à pressuposição de um traumatismo dentoalveolar, quanto às principais sequelas, relacionamentos sociais, reações esperadas dos filhos e sentimentos da criança. Métodos:

\footnotetext{
$\nabla \nabla v$

1 Universidade Federal do Espírito Santo, Curso de Odontologia, Departamento de Clínica Odontológica. Av. Marechal Campos, 1468, Maruípe, 29040-090, Vitória, ES, Brasil. Correspondence to: ECV Dadalto. E-mail: elainedadalto@gmail.com.

$\checkmark \nabla v$

How to cite this article

Flora PGO, Sarmento LC, Gomes APM, Gomes AMM, Valle MAS, Dadalto ECV. Parental perception versus the presumption of the occurrence of dentoalveolar trauma in their children. RGO, Rev Gaúch Odontol. 2020;68:e20200047. http://dx.doi.org/10.1590/1981863720200004720180060
} 
Foram selecionados 74 pais, aleatoriamente, e foram apresentadas seis fotografias coloridas, extraídas de livro, com aspectos clínicos de lesões traumáticas. As respostas foram registradas com auxilio de gravador de voz, transcritas e categorizadas por aproximação semântica. Os dados foram tabulados no programa SPSS e avaliados por estatística descritiva. Resultados: As principais sequelas atribuídas pelos pais ao traumatismo dentoalveolar foram: perder o dente (43\%) e prejudicar o dente permanente (18\%). A maioria dos pais acreditava que não haveria alteração no relacionamento das crianças com os pais (68,9\%), enquanto para $54,1 \%$ haveria afastamento das crianças da vizinhança e para 90,5\% as crianças da escola poderiam ridicularizar ou zombar. Das reações esperadas, $86,5 \%$ dos pais acreditavam que o filho se sentiria diferente em relação aos amigos devido à aparência. Quanto aos sentimentos, para 85, 1\% o traumatismo poderia ocasionar no filho sentimentos de vergonha ou constrangimento, 79, 7\% timidez ou introversão e 60,8\% tristeza. Conclusão: Concluiu-se que a perda do dente e o risco de envolvimento do germe do permanente sucessor foram as principais sequelas atribuídas pelos pais. O traumatismo dentoalveolar pode influenciar de maneira desfavorável os relacionamentos sociais das crianças com outras da vizinhança e principalmente da escola e podem se sentir diferentes em relação aos amigos devido à aparência. Além disso, as crianças poderiam sentir vergonha ou constrangimento, timidez ou introversão e tristeza.

Termos de indexação: Criança. Impacto psicossocial. Traumatismos dentários.

\section{INTRODUCTION}

In recent years, dentoalveolar trauma has been considered a public health problem due to the high prevalence, cost of treatment and the implications for the patient's oral health [1]. The concept of dentoalveolar trauma has been expanded, in that its sequelae are not limited merely to the oral condition but also the overall state of the individual, including his/her emotional stability and consequences for the family unit $[2,3]$. For this reason, traumas that involve the oral cavity should always be analyzed as a special situation, since they almost always transform into dramatic experiences for the parents and children [4].

In pre-school children, dental traumas have a negative impact on the quality of life, particularly cases of discolored crowns, enamel/dentin fracture and avulsion. However, enamel fractures do not have a significant impact, it being necessary to exclude them from studies that seek to evaluate the impact of dental traumas on the quality of life [5-7]. Fractures of both enamel and teeth had a significant impact on children's quality of life, while the same could not be said for a simple enamel fracture [8].

Dental traumas can lead to pain, loss of function and esthetic problems, with physical, emotional and social consequences for children and their families [5]. Depending on the gravity, they can culminate in serious complications of a morphological, physiological or emotional nature [9], for example: debilitated masticatory function, speech limitations, esthetic impairment and psychological problems involving social interaction, to the point of avoiding to smile or talk [10].

Permanent tooth loss in the anterior region, especially in the upper dentition, in children between the ages of 11 and 14, may lead to feelings of insecurity related to appearance, making them more shy and prone to dissatisfaction with relationships and interactions [11]. In addition, they may be concerned about being judged by others $[11,12]$.

Specifically, the esthetic impairment of the anterior teeth in children may determine a bigger psychosocial impact and influence the perception of others in relation to their appearance. Children with dental traumas in the anterior teeth suffered a negative impact on their well-being, mainly with regard to avoiding to smile or laugh and being worried about what other people might think or say [11].

In a study conducted in Great Britain, an investigation was conducted into the way in which children see their colleagues who may or may not have visible tooth fractures in their anterior teeth. Younger children viewed the photographs of children with this type of trauma more negatively compared to those whose incisors were intact. On the other hand, the converse was observed when the evaluation was made by adolescents, this difference being attributed to increased emotional maturity [13].

Based on the above, the aim of the present work was to ascertain the perception of parents vis-à-vis the presumption of a dentoalveolar trauma, with regard to the main sequelae, social relationships, the expected reaction of their children and their children's feelings.

\section{METHODS}

The present work consists of a cross-sectional, observational study and a convenience sample with parents of children between the age of 3 and 12, who frequented the Pediatric Dental Clinic of a public institution between February 2016 and January 2017. The study began after the approval of the Research Ethics Committee (CAAE: 58103516.0.0000.5060) and interviews were preceded by the signing of a Free and Informed Consent Form. 
Six color photographs taken from a book [14], and with the clinical appearance of traumas in young deciduous and permanent teeth, were shown to the parents. An interview script was then applied by the researcher, comprising both open and closed questions. The interviews were recorded and subsequently transcribed and stratified using semantic approximation, for the content evaluation procedure [15].

The questions were arranged in thematic sections with the aim of obtaining the psychosocial aspects, as well as the parents' notions of aspects related to traumatic injury, given the possibility of it happening to their own children. The thematic sections used were as follows: A) Social relationships of children vis-à-vis the presumption of an occurrence of dentoalveolar trauma; B) Expected reactions of their child vis-à-vis the possibility of the incidence of a dentoalveolar trauma.

The data were tabulated by means of the Statistical Package for the Social Sciences, version 21.0 (SPSS Inc., Chicago, IL, USA). The statistical evaluation was performed by way of a descriptive analysis, with the production of graphs and frequency tables.

\section{RESULTS}

The sample comprised 74 parents, of which 64 (86.5\%) were female and 10 (13.5\%) were male, aged between 19 and 59 (35.53 \pm 8.39 years). In total, $36.5 \%$ said they were single parents, $55.4 \%$ were in a common-law marriage, $6.8 \%$ were divorced and $1.4 \%$ were widowed. On the subject of level of schooling, it was noted that the majority of parents had completed secondary education (figure 1).

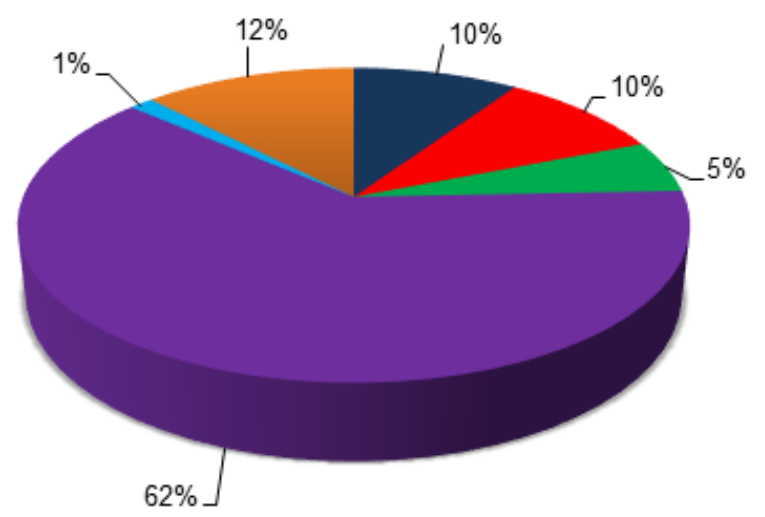

- Elementary Education (incomplete)

- Elementary Education (completed)

- High School Education (incomplete)

Figure 1. Frequency distribution of participants, according to level of schooling.
As for the children's ages, $41.9 \%$ of parents stated they had children in the 3 to 5 age range, $39.2 \%$ in the 6 to 9 age range and $18.9 \%$ between the ages of 10 and 12 . $75.7 \%$ of the children had previously visited a dentist while just $24.3 \%$ stated it was the first time.

The participants were questioned about previous experience of dentoalveolar trauma. Approximately 99\% of the sample thought it was important to look after teeth that have suffered trauma, although $70.3 \%$ had never had such an experience.

The participants were then evaluated by means of hypothetical situations. When asked about what they imagined might occur following a traumatic episode, the most frequent responses indicated sequelae such as the loss of a tooth (43.2\%), as can be seen in figure 2. Among the changes in children's behavior described by parents, accounts of whining, petulance and irritability were observed.

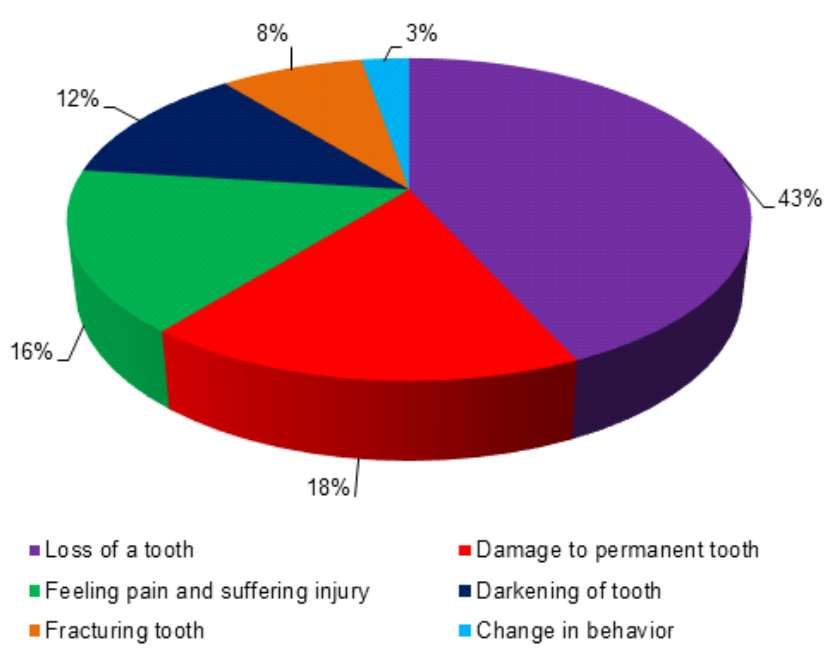

Figure 2. Sequelae ascribed by parents vis-à-vis the presumption of a dentoalveolar trauma.

The percentage of alternatives ticked in terms of social relationships, vis-à-vis the presumption of the occurrence of a dentoalveolar trauma, is displayed in table 1. Among those participants who believed there would be a change in children's relationships with their parents $(n=23 ; 31.1 \%)$, these modifications would be in the form of taking more care to avoid a fresh trauma $(9.5 \%)$, and in terms of behavior and social relations, such as feelings of anger with the situation, embarrassment or a child avoiding smiling (21.6\%). As for changes that might occur in the child's relationship with adult parents, among those parents who believed there would be a change $(n=31 ; 41.9 \%)$, these changes would constitute 
a significant motive for embarrassment (25.7\%), teasing $(5.4 \%)$, mean comments $(5.4 \%)$, prejudice $(2.7 \%)$ and alienation (2.7\%).

Table 2 lists the results in relation to the expected reactions of the child vis-à-vis the possibility of dentoalveolar trauma. Among the participants who said that the trauma might modify the child's behavior $(n=56 ; 75.7 \%)$, the majority (58.1\%) mentioned that he/she might become introverted, and $17.6 \%$ believed they would have problems of a social nature, such as bullying. In figure 3, the responses of the parents can be observed with regard to the sentiments that a trauma might provoke in their child, and $85.1 \%$ believed their children might feel ashamed or embarrassed.

Table 1. Social relationships of children vis-à-vis the presumption of the occurrence of dentoalveolar traumas.

\begin{tabular}{|c|c|c|c|c|}
\hline \multirow{2}{*}{ Social relationships } & \multicolumn{2}{|c|}{ Yes } & \multicolumn{2}{|c|}{ No } \\
\hline & $\mathrm{n}$ & $\%$ & $\mathrm{n}$ & $\%$ \\
\hline Influence and change in children's relationship with parents & 23 & 31.1 & 51 & 68.9 \\
\hline Negative impact on children's relationship with adult parents & 31 & 41.9 & 43 & 58.1 \\
\hline Alienation of neighborhood children & 40 & 54.1 & 34 & 45.9 \\
\hline Alienation of school friends & 44 & 59.5 & 30 & 40.5 \\
\hline Schoolchildren might tease or make fun of a child who has suffered a trauma & 67 & 90.5 & 7 & 9.5 \\
\hline
\end{tabular}

Table 2. Expected reaction of child faced with the possibility of dentoalveolar trauma.

\begin{tabular}{|c|c|c|c|c|}
\hline \multirow{2}{*}{ Expected reactions } & \multicolumn{2}{|c|}{ Yes } & \multicolumn{2}{|c|}{ No } \\
\hline & n & $\%$ & $n$ & $\%$ \\
\hline Could the trauma modify the child's behavior? & 56 & 75.7 & 18 & 24.3 \\
\hline $\begin{array}{l}\text { Could the trauma provoke feelings of dissatisfaction or annoyance in their child, with regard to } \\
\text { appearance? }\end{array}$ & 58 & 78.4 & 16 & 21.6 \\
\hline Would their child feel different in relation to friends because of their appearance? & 64 & 86.5 & 10 & 13.5 \\
\hline For the child, would there be some limitation or restriction in social relationships? & 52 & 70.3 & 22 & 29.7 \\
\hline
\end{tabular}

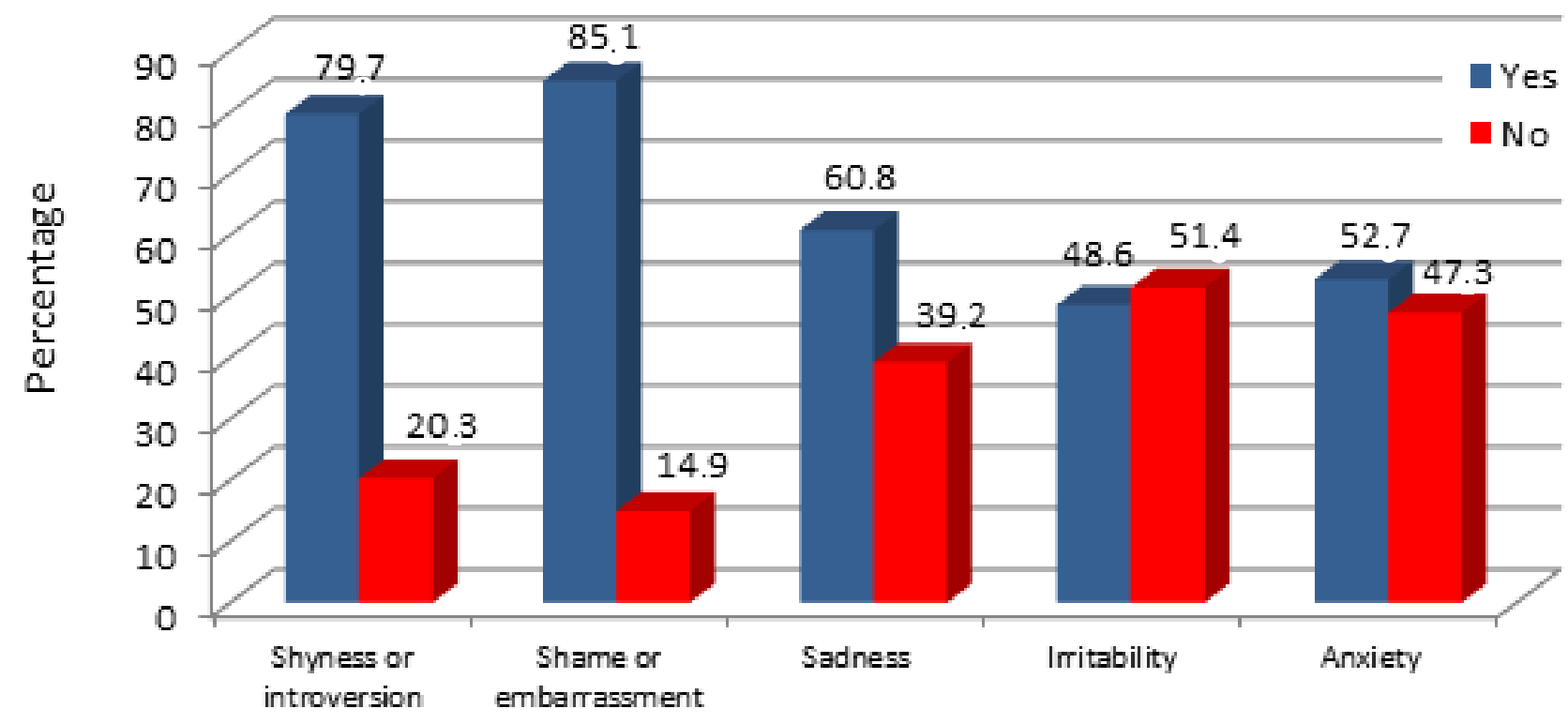

Figure 3. Feelings that a dentoalveolar trauma might provoke in the child. 


\section{DISCUSSION}

Approximately $99 \%$ of parents considered care of teeth affected by dentoalveolar trauma to be important. This finding repudiates the assertion that many parents do not acknowledge the impact of dentoalveolar trauma on diurnal activities and their children's quality of life [16]. In one longitudinal case-control study, dental traumas did not have a negative impact on the quality of life in pre-school children [17]. However, in a systematic review study, using meta-analysis, the principal findings indicated that the presence of dental traumas causes a negative impact on the oral-health related quality of life in pre-school children. It is important to stress that the degree of severity of the dental trauma may be related to the greater impact on the quality of life of preschoolers [5].

The majority of participants reported no changes or negative influences in respect of the children's relationships with their adult parents. On this point, there is some disagreement with regard to the conclusions of other studies that reveal a heavy influence on activities and emotions, resulting in family conflict $[2,4]$.

The results of this study also point to the fact that the neighborhood's children and school colleagues could distance themselves from these children. Although part of a scenario that differs from the study in question, one study carried out recently in Sudan, based on the evaluation of standardized photographs, looked into the way the children view their colleagues, whether or not they have a visible dental trauma in the incisors. Those children with traumas were looked upon more negatively than those who did not have any trauma [18].

It was found that $90 \%$ of the parents believed that schoolchildren might tease or make fun of a child who has suffered a dentoalveolar trauma. These findings may be compared with a study conducted in Korea into violence amongst adolescents, which showed that victimization is, among other factors, associated with dissimilarities, such as appearance, among groups of adolescents [19].

With regard to the expected reactions of the child, it was found that dentoalveolar trauma would probably modify his/her behavior. This analysis is in line with studies which asserted that esthetics, in the psychosocial context, have a direct relationship between untreated traumas and social wellbeing, and could lead to social, behavioral changes, particularly with regard to avoiding to smile or laugh and being worried about what other people might think or say [11].

In addition, $78.4 \%$ of parents reported that dentoalveolar trauma could cause the child to be dissatisfied or upset with regard to their image. This item of data is consistent with previous studies that revealed that, associated with pain and infection, the consequences of dental trauma also include changes in physical appearance, speech defects and emotional impacts that affect the child's quality of life $[5,9,10]$.

The parents stated that, because of his/her appearance, the child would feel differently in relation to his/her friends, and that, as far as the child is concerned, there would be limited or restricted social relationships. With regard to the feelings that traumas might produce in the child, the data presented in this study showed that children may feel shame or embarrassment, shyness, sadness, anxiety, which validate the literature, also adding that the children might feel less prone to speaking, smiling or laughing $[9,10,12]$. However, $51.4 \%$ of parents stated that the fracture of an anterior tooth does not predispose the child to irritable behavior, contrary to what some researchers have asserted [17]. The highest prevalence of the impact of trauma is related to pain (19.4\%), followed by difficulty in ingesting certain foods (16.4\%), difficulty in drinking (11.9\%) and irritability or frustration (11.9\%) [19].

The findings indicate the need for programs of prevention, early diagnosis, immediate treatment of traumatic injuries occurring in early infancy, to avoid detrimental conditions, as well as preventive measures such as the control of risk factors, including guidance on the safety of the target environment [5].

This study contains a number of limitations, most notably the sample size, it being a reduced, non-probabilistic and convenience sample, which limits the possibility of extrapolation to the general population. Future investigations should also consider individual characteristics of children and other factors not targeted in the present study. Nonetheless, this study does present important findings that show that dentoalveolar trauma can create psychosocial impacts. As a result, the implementation of targeted educational programs and measures is suggested, both for the community and the schools, that seek to promote prevention and a reduction in the rates of dentoalveolar trauma, encouraging immediate treatment to be sought when faced with this complication. 


\section{CONCLUSION}

The main sequelae ascribed by the parents, vis-àvis the presumption of a dentoalveolar trauma, is the loss of the tooth and the risk of the germ of the permanent successor tooth becoming involved. The parents believe that dentoalveolar traumas could have an unfavorable impact on the social relationships of children with others in the neighborhood and mainly at school. Dentoalveolar trauma may cause sudden, negative changes in conduct and affective behavior, also making the children feel different to their friends in relation to appearance. As regards feelings, the majority of the parents believe that the children could experience shame or embarrassment, shyness or introversion, and even sadness.

\section{Collaborators}

PGO FLORA, research and data collection. LC SARMENTO, data collection and text reading. APM GOMES, blibliographic survey and final writing. AMM GOMES, final writing; MAS VALLE, elaboration of the project. ECV DADALTO, elaboration of the project and statistics and final writing.

\section{REFERENCES}

1. Melo JRT, Silva AL, Freitas Neto JS, Botelho KVG, Pedrosa RF. Reabilitação oral pós-traumatismo dental: Uma proposta estética, funcional e psicológica para o tratamento conservador. Recife: Ciênc Biol Saúde. 2015;2(3):99-108.

2. Bendo CB, Paiva SM, Abreu MH, Figueiredo LD, Vale MP. Impact of traumatic dental injuries among adolescents on family's quality of life: a population-based study. Int J Pediatr Dent. 2014; 24(5):387-96. http://dx.doi.org/10.1111/ ipd.12083

3. Porritt JM, Rodd HD, Baker SR. Childhood dental injuries: a resiliency model of adaptation. Int J Paediatr Dent. 2015;25(4):267-81. http://dx.doi.org/10.1111/ipd.12139

4. Porritt JM, Rodd HD, Baker SR. Quality-of-life impacts following children's dento-alveolar trauma. Dent Traumatol. 2011;27(1):2-9. http://dx.doi.org/10.1111/j.1600-9657.2010. 00943.x

5. Borges TS, Vargas-Ferreira F, Kramer PF, Feldens CA. Impact of traumatic dental injuries on oral health-related quality of life of pre school children: A systematic review and meta-analysis. PLoS One. 2017;12(2):e0172235. http://dx.doi.org/10.1371/ journal.pone.0172235

6. Ortiz FR, Ramadan YH, Gonzalez RAB, Ardenghi TM. Fatores associados com a qualidade de vida relacionada à saúde bucal de pré-escolares no sul do Brasil. RGO, Rev Gaúch Odontol. 2016;64(3):256-262. http://dx.doi.org/10.1590/1981-86372 0160003000033254
7. Feldens CA, DAY P, Borges TS, Feldens EG, Kamer PF. Enamel fracture in the primary dentition has no impact on children's quality of life: implications for clinicians and researchers. Dent Traumatol. 2016;32(2):103-9. http://dx.doi.org/10.1111/edt.12 222

8. Soares JP, Barasuol JC, Torres FM, Giacomin A, Gonçalves BM, Klein $D$, et al. The impact of crown fracture in the permanent dentition on children's quality of life. Dent Traumatol. 2018;34(3):158-63. http://dx.doi.org/10.1111/edt.12400

9. Vasconcellos RJH, Oliveira DM, Nogueira RVB, Maciel AP, Cordeiro MC. Trauma na dentição decídua: enfoque atual. Rev Cir Traumatol Buco-maxilo-fac. 2003;3(2):17-24.

10. Traebert J, Marcon KB, Lacerda JT. Prevalence of traumatic dental injuries and associated factors in school children of Palhoça, Santa Catarina State. Ciênc Saúde Coletiva. 2010;15(1):1849-55. http://dx.doi.org/10.1590/S1413-8123 2010000700098

11. Bendo CB, Paiva SM, Torres CS, Oliveira AC, Goursand D, Pordeus IA, et al. Association between treated/ untreated traumatic dental injuries and impact on quality of life of Brazilian school children. Health Qual Life Outcomes. 4;8:114. http://dx.doi.org/10.1186/1477-7525-8-114

12. Antunes LAA, Leão AT, Maia LC. Impacto do traumatismo dentário na qualidade de vida de crianças e adolescentes: revisão crítica e instrumentos de medida. Ciênc Saúde Coletiva. 2012;17(12):3417-3424. http://dx.doi.org/10.1590/ S1413-81232012001200026

13. Rodd HD, Barker C, Baker SR, Marshman Z, Robinson PG. Social judgments made by children in relation to visible incisor trauma. Dent. Traumatol. 2010;26(1):2-8. http://dx.doi.org/10. 1111/j.1600-9657.2009.00849.x

14. Andreasen JO, Andreasen FM. Texto e atlas colorido de traumatismo dental. $3^{\mathrm{a}}$ ed. Porto Alegre: Artmed; 2001.

15. Bardin L. Análise de conteúdo. Lisboa: Edições; 1977.

16. Ramos-Jorge ML, Ramos-Jorge J, Mota-Veloso I, Oliva KJ; Zarzar PM, Marques LS. Parent's recognition of dental trauma in their children. Dental Traumatol. 2013;29(4):266-71. http:// dx.doi.org/10.1111/edt.12005

17. Vieira-Andrade RG, Siqueira MBL, Gomes GB, D'Avila S, Pordeus IA, Paiva SM, Granville-Garcia AF. Impact of traumatic dental injury on the quality of life of young children: a casecontrol study. Int Dent J. 2015; 65(5): 261-8. http://dx.doi. org/10.1111/idj.12182

18. Awooda EM, Ali YA. Social judgments made by children (10-15 year old) in relation to visible incisors trauma: Schoolbased cross-sectional study in Khartoum state, Sudan. J Int Soc Prev Community Dent. 2015;5(5):425-31. http://dx.doi. org/10.4103/2231-0762.165931

19. Park S, Lee $Y$, Jang $H$, Jo $M$. Violence victimization in Korean adolescents: Risk factors and psychological problems. Int J Environ Res Public Health. 2017;14(5):541. http://dx.doi. org/10.3390/ijerph14050541

Received on: 13/11/2018 Final version resubmitted on: 16/4/2019 Approved on: 17/9/2019 